\title{
Verbal and Nonverbal Communication Behavior Parents with Youth Active Gadget Users
}

\author{
Mimi Fahmiyatri \\ Neni Efrita, M.Si \\ Ernita Arif, M.Si \\ Communication Science Master Program \\ Faculty of Social and Political Sciences \\ Andalas University Padang
}

\begin{abstract}
Communication is very important in human life. People communicate with everyone, everywhere and every time. In communicating, humans cannot be separated from the verbal and nonverbal behavior. In the digital era, as now, are becoming increasingly sophisticated communications technology with the creation of the "current" which is known as Information and Communication Technology (ICT). Advances in technology have provided a huge influence for human life, especially youth's active gadget users. Basically, gadget has a function as a tool for facilitating people for communicating, but it can be the cause of things that are not good. This study uses descriptive qualitative data analysis with case studies paradigm. The purpose of this study was to analyze the behavior of verbal and nonverbal communication used by parents in communicating with their teenager who have characteristics as youth's active gadget users. The results showed that verbal communication used by parents with their teenagers was using Minang language. While nonverbal behavior found in parents' nonverbal communication with their teenagers is to use facial, gestural and postural movements.
\end{abstract}

Keywords: Verbal and Nonverbal Communication, Parents and Teens, Gadgets.

\section{Introduction}

\subsection{Background}

Communication is very important in human life. People communicate with everyone, everywhere and every time. In the digital era, as now, are becoming increasingly sophisticated. It is causes the creation of the "current" which is known as Information and Communication Technology (ICT). The rapid advancement of ICT leads to loss of distance limits, time and space. One of the most popular uses of ICT is the use of the internet. Through internet, people are easily to access various kinds of information in the world.

According to a survey conducted by the Indonesian Internet Network Organizing Association (APJII), more than half of Indonesia's population is now connected to the internet. The survey conducted throughout 2016 found that 132.7 million Indonesians were connected to the internet. The totals of Indonesia's population itself were 256.2 million. This indicates rise of 51.8\% which compared to the number of internet users in 2014 are only 88 million. Most were accessed via gadget devices. The survey results from APJII show that the number of gadget users is increasing. The second largest gadget user in Indonesia is adolescents (aged 18-25 years) as much as $49 \%$. This condition causes unstable teenagers are vulnerable to exposure to the bad things caused by excessive use of gadgets, including: lazy for learning / lack of attention to the lesson, lazy to help parents, sleeping late, forgetting time, being exposed to images and porn videos, tend to get bored quickly when people advise them, and live less regularly.

Advances in technology have provided a huge influence for human life. Humans always use technology in their life. In the morning, many people wake up by an alarm, then immediately turn on the television, and turn on the mobile phone or computer for check email or facebook (Morissan, MA, 2010: 30).

Nowadays, human have relied on technology. Humans use technology when working and even at bedtime. Realize or not, the technology has become a primary needs for every people. Gadgets, small tools created by experts that are very useful. 
On the other hand, gadgets are present to provide convenience for the lives of many people. The gadget is equipped with interesting features and applications that provide convenience for its users in their daily needs such as work, entertainment, health and etc. Furthermore, gadget also has given the bad influence for the users.

The Oxford Dictionary states that gadgets are identical with small mechanical devices, sometimes the shape is not clear, but this tool must be clever and new. Another opinion states that the term gadget comes from French, namely gachette, which in Indonesian means sparking or giving birth to a new idea. Until 1956, the term gadget continued to be discussed. An architectural critic, Reyner Banham in his essay "The Great Gizmo" defines gadgets as objects with unique characteristics, having high-performance units and relating to the size and cost that serves to transform things into things that humans need. Based on this, it is not surprising that mobile phones, laptops, tablets, are categorized as gadgets. Based on its function, those three tools are most needed by human every day.

Mobile phones were originally just to talk and send text messages yet the function of cellphone is beyond than we can expect today. A compatible screen from monochrome developed into a qualified-screen compare to a television. Furthermore, the use of keypad button is being replaced by using touchscreen. In addition, high quality camera is also integrated into cellphone to make the phone be more elegant and modern looks like. Moreover, cellphone is becoming one of human primary needs nowadays. We can find the latest cellphone update from various brand and design. There are types of cellphone like bar, flip, and slide. According to Reyner Banham, gadget change cellphone become closer, familiar, smarter and significantly needed to human.

(http://www.merdeka.com/peristiwa/asal-usul-gadget.htmlcg4).

Nowadays, the gadget has become the needs of everyone. The use of gadgets makes it easy for humans. However, if we are not good for using, so the gadget will cause negative things. Using the gadget too long can also cause addiction. Therefore, people must be smarter and wiser than the gadgets they use. The characteristic of someone who is addicted for using gadget looks as described by Irma Gustiana Andriani, M.Psi on her seminar "Smart Parents in the Digital Era":

1. Users are not interested in other activities.

2. More than two hours a day using gadgets continuously

3. There is change in behavior such as being angry / tempered, and mood swing.

4. Lazy to maintain cleanliness and health of himself

Therefore, according to Irma, parents should know about the right use of gadget. It has taken over the communication between teenagers and their parents so that they are too busy with it and parents also do not monitor their children properly. In fact, children are in their rooms and busy with gadgets, while parents do not know what their children are doing. Parent give their children a gadget precisely smartphone in purpose to make them stay in touch. But for the children, the function of gadget moves into something other to gain consolation. Gadget served people many things by using internet. There are various interesting applications and contents which served in the internet, such as online and offline game, video, comic, even pornography and other negative things. It makes the children susceptible touch by pornography content, even unintentionally influence by the unexpectedly advertisements appear in the smartphone. Communication between parents and their children is limited by gadget, while communication both of them is very important. Teenager will enter the transition phase. This phase, teenagers are very unstable where they face various problem from them self or others it's like problem from school, pressure from group etc. so that is why communication plays important role.

Interpersonal communication between parents and their children is one of important factor for growth in all of ages especially for teenagers that susceptible and desire for free and considered and adult. The expected is the effective communication that appearing understanding, happiness, the good relationship, and influence for attitude and action. Thus, it is hopes to make effective communication between parents and their children so the relationship becomes harmonious. (Effendi, 2002:28)

Interpersonal communication is very important because it will make a logical communication in compared to other communication. It change attitude, believe, and behavior so that's why this communication often use to expedite persuasive communication that has delicate, flexible like invitation, and persuasion (Effendi, 2002:59). Communication in family have two kinds of communication, there are verbal and nonverbal communication. 
As human social, we need communication to communicate with others. It happens if we do interpersonal communication. It is interaction between two or more people directly so the other people also respond directly. Interpersonal communication is often carried out verbally and also carried out with high intensity to form close relationships. Interpersonal communication has different level according to the depth of communication, intensive level and extensive level. Interpersonal communication who has just met will different between friends or between husband and wife. So, interpersonal communication will help us to know the characters deeply.

Based on the background above, the researcher is interest in analyzing parents with youth active gadget users in Kecamatan Kuranji Padang. The researcher chooses this area because the teenagers has been used gadget and found cases that have relation with the characteristic of active gadget users. The researcher will analyze about verbal and nonverbal communication between workers parents and have different background. Based on the stated above, the researcher formulate the research question as follow: how is the verbal and nonverbal communication of parents with youth active gadget user? The purpose of the study was to analyze verbal and nonverbal communication between parents and youth active gadget user in Kuranji Padang.

\section{Review of Theory and Research Methods}

\subsection{Theory Review}

\subsubsection{Verbal Communication Behavior}

Generally, communication is every form of a person's behavior both verbally and nonverbally that is responded by others. Communication has a larger interpretation rather than just dialog. Every single behavior which reveal particular message, so then it builds a form communication. Communication is defined as a message sent to someone or more recipients in order to influence the recipients' behavior. Johnson (Edi Harapan and Syarwani Ahmad, 2014:3) states that in each form of communication there are at least two people sending symbols to each other that have certain meaning. These symbols can categorize as verbal in the form of words or non-verbal like expression and gesture. Verbal communication represented by verbal symbolizes. According to Deddy Mulyana (2000), language can be considered as verbal code system. Language can be defined as a set of symbols, with rules to combine these symbols, which are used and understood by community.

There are several important elements in verbal communication as follow:

1. Language

Language basically is a system that allows people to share meaning. In verbal communication, the symbols are used in the form of verbal in spoken, written on paper even electronic. Language of a nation or tribe appears as the result of peoples' interaction and relation to each other.

Language has many functions, yet at least there are three functions that are closely related to create an effective communication. Those are:

a. In order to learn the world around.

b. In order to foster a good relationship to each other as human being

c. In order to create bonds in human life.

How to understand language? Based on the experts, there are three theories that explain about how can people have language ability.

The first theory known as operant conditioning which developed by an expert of psychology behavioristic named B.F Skinner in 1957. This theory focuses on stimulation and responses or known as S-R. it says that if an organism is being stimulated from the outside then it will give feedback. Parents teach their children about language and they imitate what others' said.

The second theory is cognitive theory developed by Noam Chomsky. He said that the speaking ability lay in human gene since they were born.

The last theory called mediating theory by Charles Osgood. It said that human in developing speaking ability is not only depend on outside stimulation but also being motivated by the inside of themselves.

2. Word

Word is the smallest core in language. Word is a symbol which representing something, person, event, and situation. Thus, word is not human being, thing, event, or situation itself. The meaning of word is out beyond human mind. 


\subsubsection{Nonverbal Communication Behavior}

Nonverbal communication is a communication without words. In fact, nonverbal communication is often use than verbal communication. Nonverbal communication is automatically used in communication. Therefore, nonverbal is permanent and available. Nonverbal communication is more integrity for expressing something spontaneous. Nonverbal communication is all aspects of communication other than words themselves. It includes how we utter words (inflection, volume), features, of environments that affect interaction (temperature, lighting), and objects that influence personal images and interaction patterns (dress, jewelry, furniture).

Nonverbal communication is including body language, sign, action and object. Body language. Body language is including face, motion head and hand, gesture that shows some feeling, idea, desire, and attitude.

Sign. In nonverbal communication, the sign change the words, such as flags, traffic sign, and command.

Action. Actually, action does not have meaning to change the words, but it use to convey meaning. It is like hit the table around the conversation, slammed the door when leave the home, pressing the car with very strong. All of them have a meaning.

Object. Object as nonverbal communication also don't change the words but can convey the meaning. Such as clothes, accessories, houses, furniture, property, vehicles, and gifts.

According to Albert Mahrabian (1971), the credibility level of someone is 7\% from verbal language, $38 \%$ from vocal voice, and 55\% from facial expression. If someone speaks and do that different with the act, so others tend to believe with nonverbal.

In addition, Mark Knapp (1978) stated that the functions of using code in nonverbal communication are:

a. Convince what he says (repetition)

b. Showing the feeling and emotion that cannot be expressed (substitution)

c. Showing the identity (identity)

d. Completing the words

\subsection{Research Methods}

This research is qualitative research. According to Sugiyono (2014), qualitative research is also called as naturalistic research because this research is in natural condition (natural setting). This research is divided into some approach.

Cresswell in Sugiyono (2014) divides qualitative research into 5, there are: Phenomenology, Ethnography, Case Study, Grounded Theory, and Narrative. In this research, researcher used case study as the research design. Participants in this research chosen deliberately and used purposive sampling by considering the similarities and the differences background of the family include parent's occupation from the participant. In this case, the researcher approach with participant's family, and come to participant's house and asked everything that the researcher need so the researcher make a story with the participants and their parents. The total of participants is eight participants that consists 3 of teenagers $(\mathrm{A}, \mathrm{B}, \mathrm{C})$ and their parents. Technique of the data collection was observation and interview. Meanwhile, technique of the data analysis in qualitative research, has been collected and analyzed by interpreting and describing the subject or object in this research. Therefore, this research used data analysis technique by Miles and Huberman who share data analysis qualitative research into 3 stages, there are: data modification, data presentation, and conclusion or verification data. This method needs interpreting data based on the facts because this facts should be analyze once to get in new theory (Iskandar, 2009:284)

\section{Discussion}

\section{Results and Discussion}

\section{Analysis of Parents' Verbal and Nonverbal Communication Behavior with Youth Active Gadget Users}

\subsection{First Family Case}

Participant (A) was graduated of an Islamic Boarding School Junior High School in Payakumbuh. As a student there, she is very kindness and have good manner with her parents. As long as on school, she has good Al-qur'an memorization.

Furthermore, participant (A) was not allowed bring and used gadget or cellphone to communicate with her parents. Parents, who wanted to contact their child, should contact the teacher on boarding school. 
Meanwhile, to visit their child, the parents should be waiting the schedule. The parents are able to bring out their child from boarding school just for a few hours. Besides, for come back to home participant (A) must wait the time that has been scheduled by boarding school.

After graduated, participant (A) chosen to continued her study in Padang because she wanted to close with her parents. Furthermore, the parents agreed with her decision because for a long time they cannot meet each other and it is enough to have basic religion knowledge for her.

In padang, participant (A) decide to study in Vocational High School and lived with her parents. Besides, her parents give her a cellphone to make communicate more easily. They hoped this cellphone was able to make a communication better. In other side, there are so many applications that can be accessed in android and make participant (A) be addicted with her cellphone. Unexpectedly, the communication between both of them is more difficult, because her child used the gadget just for play the game. She is very addict with her game till she forgot about the function of the cellphone that hoped by her parents.

In conclusions, parents must be able to make a good communication with her child (participant A), they should show how their feeling, what they want, and what they think. In this phase, all teenagers want to show who they are in transition phase. The parents must be able to know the things that faced by their child when they become a teenagers.

\section{Analysis of Verbal Communication Behavior between Parents and participant $A$}

Based on the interview between researcher and participant A's parents, it showed that the parents always gave their attention to the child. It can be showed with how the parents always woke up their child every morning. They did want their child came late to the school. The interview between researcher and parent: (Friday, $9^{\text {th }}$ February 2018).

$\mathrm{X}$ : mom, how about Participant (A)? Does she go to training?

Y : I do not know, I am so dizzy to see my daughter. I told her but she does not answer. She always avoids me. Is she not afraid if her score is not appeared by her teacher? I am worried to see this.

$\mathrm{Y}$ : The participant always uses her cellphone. Does she use the cellphone for communicate?

$\mathrm{X}$ : If I call her, there is no response. I do not know why.

Based on the interview above, it can be seen that the communication between both of them was not run well. It showed that in "I told something to her but there is no response". It means that there is no response that hoped by parents. Besides, when parents talk with her child, she should pay attention to her parents. It is wrong when a child does not give response or go out from her parents. So, verbal communication, that used by both of them to make a communication is minang language.

2. Analysis of Nonverbal Communication Behavior Between Parents and participant A Nonverbal communication that happened between parents and participant A can be analyzed in facial expression (face), body language and intonation and can be sees on the function of nonverbal message.

a. Body language

1. Facial movement

Researcher analyzed the facial expression seen on participant A when s/he was invited to communicate by her/his mother, the participant A did not take a look toward her/his mother. In the time, the participant A avoided her/his mother when she talked to her/him and ran away instead. The facial expression of participant $\mathrm{A}$ is representing that s/he did not interest to engage into a conversation with her/his mother, it can be seen from the facial expression when s/he did not look into her/his mother who talked to her/him.

2. Gestural movement (the movement of some members of the body) and postural movement (the movement of the whole body)

There was a chase on between the participant $\mathrm{A}$ and her/his mother, even running around the dine table. It shows that participant A was evaded and was not willing his/her mother. The interpretation of this situation is: Immediately, what shown by participant A is an expression of how s/he dislike to communicate with his/her mother. There was a step away movement by the participant A toward his/her mother when she invited him into a conversation. 
As powerfully, it can be seen that participant A do not respect his/her parent who talked to her/him and s/he broke the courtesy norm trough parents. Responsively, participant A shows a negative emotion.

b. Intonation

The intonation that was heard during the dialog between mother and participant A was that participant A only muttered. It shows that participant $\mathrm{A}$ is rather lazy and s/he does not want to response her/his mother.

c. The function of nonverbal message

Based on the nonverbal message function, the message conveyed by the participant A trough his/her mother is a regulator function, the unwillingness to communicate. This is seen in the response of participant A when s/he left the conversation.

\subsection{Second family case}

Unlike participant A, participant B has graduated from high school for a long time. Even he is 23 years old now and has not been married yet. He also has not get a job. He used to work as a driver and even traveled to Mentawai and Jakarta. But soon he returned to Padang and become unemployed. Only at home, getting lazy and playing gadget. According to his mother, at the time the researcher asked whether participant B often played gadget, his mother admitted that participant B did often play gadget and even used his mother's cellphone. His mother, a retired teacher, told the researcher that he was dizzy thinking about her son. Sometimes she does not understand anymore about her son who does not want to do anything else. Whereas he is growing old by years while his future still unrecognized what will be like.

\section{Analysis of Verbal Communication Behavior between Parent and Participant $B$}

Based on the conversation between the researcher and the parent, researcher knows that participant B is a temperamental person. It can be seen during the interview between the researcher and the parents of participant B on Sunday 18 February 2018.

Y: I'm confused about this kid. He does nothing. I asked him to get a job he refused. A lot of his friends came along yesterday.

$\mathrm{X}$ : what is up with RB mam?

Y: it was his birthday. His friends came along visited him. They were playing around while they get older by years.

$\mathrm{X}$ : does he still often playing cellphone?

Y: yes, he does, he used my phone sometimes. I do not have any idea what should I do anymore. If I give advice him then he gets angry to me. I do not know he worried me. I do not know what will he is going to be like.

According to the interview, it can be said that the communication occurs between the participant B and his parent is not going well. There were none of his words give a positive response when they get into a conversation, even his mother felt worry if she asked him he will get angry at her when she told him to stop playing gadget. It can be seen in her words "he often plays game. He used my phone sometimes. I can say nothing. If I give him advice, he gets angry at me. I do not know anymore, he worried me. I do not know what will he is going to be like". From the statement, researcher knows that participant B is hard to get him into a conversation by his parent.

\section{Analysis of Nonverbal Communication Behavior between Parent and Participant B}

The nonverbal communication behavior occurs between the participant B and his parent can be analyzed toward the body language like the facial expression, gestural movement, postural movement and intonation also from the function of nonverbal message.

1. Facial expression

Analyzing the facial expression of the participant B when he invited to a conversation by his mother, he showed an anger expression. The communication is not going well as expected by his mother. There was not happened the agreement between the meaning and the perception when the mother of participant B expected him to listen to what she said. On the other hand, it seems that the participant B hated to be ordered to find a job. It showed from his facial expression that getting anger when his mother told him.

\section{Gestural movements (movements of some limbs) and postural (overall movements of limbs)}

From participant B indicate the meaning: In immediacy, the meaning that shows from the parents is expression of anger. 
It was showed in the way B teenagers respond to his mother by continuing to play games without looking at his mother. In power, it can be seen that B teenagers do not respect their parents who are talking. In responsiveness, participant $\mathrm{B}$ shows a negative emotional attitude.

\section{Intonation}

Based on the mother of participant B, it can be said that participant B communicate his expression and mind by anger intonation.

\section{The function of nonverbal message}

Based on nonverbal message function, the message from teenager B to his mother is affect display function. It shows the raise of emotion that can be called by angry.

\subsection{Third Family Case}

Participant $\mathrm{C}$ is a student of university in Padang. He is 20 years old. His father is "Becak" driver and his mother is housewife that has a small shop in her house. Lately, the small shop is always close because she always visits her son in town. She feels loneliness in her house. Her husband works all day. She has 4 children and just participant $\mathrm{C}$ that stay at home. The three brothers have been married and have their own families. So it can be said that the mother did not have a friend to talk.

If participant $\mathrm{C}$ at home, his mother was always angry with him. Therefore, teenager $\mathrm{C}$ did not feel at home. Besides, He always played with his friend in outside. Talking about gadget, he said that he also play the game online because his entire friend play the game online. "I play the game because my entire friend also play the game online, like Uni said the millennium teenager, and everywhere we meet, we always play mobile legend" (Wednesday, $17^{\text {th }}$ January 2018 at 16.10 WIB)

According the interview with participant $\mathrm{C}$, can be known that he like play the game online. It cause from his friend. But, the researcher also found that participant $\mathrm{C}$ plays the game online at the home too. His mother feels difficult to ask to him for helping her at home.

His mother was always angry, so she can saying rude to her son. Such as: "Hey you, I have just washing plate, and I wash your cloth, and everything I have done. You don't wash your plate after you eat, I cannot. If you don't want to help me, don't back home!!" (She was pointing him and sighed) (Sunday, January 21 2018 at 11:05 WIB)

\section{Analysis of Verbal Communication Behavior between Parent and Participant C}

Based on interview with the parents of teenager $\mathrm{C}$, it can be said that the parents was rarely to communicate in verbal with his son. As we saw at interview the researcher with his father (Friday, 9 February 2018 at 17.30 WIB)

$\mathrm{X}$ : Is RC's mother alone at home?

Y : Yeah, but now she was not at home about one week. I am also not at home. I do know what to do, so $\mathrm{i}$ decide to go first before going home.

$\mathrm{X}$ : Do you work all day?

Y : I am not work all day, not strong anymore. I do not know what to at home. RC is boy. Sometimes he cannot talk together with his mother. He always doesn't back at home.

From the interview above, we can see that the mother of participant $\mathrm{C}$ is always alone at home and she feel lonely. She always comes to the researcher's home for talk together. She always comes at evening or after Maghrib. She said that feels lonely and complain about the works that never end. Then participant $\mathrm{C}$ did want to help her.

(Saturday, February 17, 2018 at 8:00 p.m. WIB)

$\mathrm{X}$ : How long you in sijunjung? Is she ok? (The researcher ask about her daughter)

$\mathrm{Y}:$ She is well. Actually she is not permit me for back home, but I remember my home

$\mathrm{X}$ : Is RC at home?

$\mathrm{Y}: \mathrm{He}$ is at home. But he is school. Ha, like this if you have small children. They will follow us wherever we go. Like me, 4 children, and there is no here. RC is here but he always back home lately from college. It is very feels caring them when they was a little 
$\mathrm{X}$ : It has other pleasure when caring the children when they were a little. If they are growth, they will not follow us anymore. Like you, there is children that follow you

Y : Yes, like you said, if they are being adolescent, we feel loneliness. Like RC, although he is at home, he does not want to help me for keeping home. I wash his cloth. If $\mathrm{i}$ am angry, he just silent

$\mathrm{X}$ : If he is at home, what is he doing? Does he play the cellphone?

$\mathrm{Y}$ : Yes, he just plays his phone at the home

$\mathrm{X}$ : Everywhere is almost the same. It is same with RA. Sometimes she brings cellphone when she goes to the toilet. I am confuse to see that

Y : Yeah like that

$\mathrm{X}$ : Is he angry if you talk to him?

$\mathrm{Y}$ : We just get tired. And he just keeps silent

Based on interview above, it can be said that verbal communication between parent and her son is limited because he always not at home. If his mother is angry, he will keep silent. While, his father works all day so his mother is just alone at home. That is why his mother feels loneliness. However, if he is at home, his mother always angry to him because he is difficult if she ask to help her. It can be conclude that the verbal communication between parents and their children is not good. In addition, his mother always uses verbal language that not good likes "den" and "waang".

\section{Analysis of Nonverbal Communication Behavior between Parent and Participant $\mathbf{C}$}

How the behavior of nonverbal communication that occurs between parents and participant $\mathrm{C}$ can be analyzed by looking at body language of facial movements (face and facial features), gestural movements (movements of some limbs), postural movements (overall movement of limbs) and intonation (volume of voice / intonation) and also can be seen what is the nonverbal message function.

a. Body language

1. Facial movement

An analysis from facial movement mother of participant $\mathrm{C}$, so the meaning is she shows the anger

2. The gestural movements (movements of some limbs) and postural movements (overall movement of limbs) that shows from the parent is with pointing to his T-Shirt, so the meaning is:

In immediacy, the meaning that shows from the parents is expression of anger. In power, the parent shows a higher status than participant $\mathrm{C}$. In responsiveness, the parents show the negative emotion. In other hand, if we look from teenager side, so the silent from teenager shows that in immediacy, he shows dislike to his mother. In power, he shows the lower status than his mother. In responsiveness, participant $\mathrm{C}$ show the positive emotion

b. Intonation (voice volume or intonation)

The intonation that sounds is participant $\mathrm{C}$ just keep silent and his mother talking with high intonation that show his mother is angry with teenager

c. The message function

Based on the nonverbal message function, the message conveyed by the mother is to strengthen, emphasize and complete verbal behavior. In this case, the mother is angry with pointing her son.

\section{References}

A Devito, Joseph. 1997. Komunikasi Antarmanusia. Jakarta: Professional Books.

Alan, Evision. 1993. Oxford Learner's Pocket Dictionary New York : Oxford University Press.

Berlo, David k. 1960. The Process of Communication. New York. Holt, Rinehart and Winston.

BimoWalgito. 2002. Pengantar Psikologi Umum. Yogyakarta: Andi Offset.

Barnlund. 1970.Transactional Model of Communication. Harper \& Row (New York, USA).

Daryanto. 2010. Teknologi Jaringan Internet. Bandung: PT Sarana Tutorial Nurani Sejahtera.

Effendy, OnongUchjana. 1989. KamusKomunikasi. Bandung: MandarMaju.

2002. Ilmu, Teori dan Filsafat Komunikasi. Bandung: PT. Citra Aditya Bakti.

Harapan, Edi dan Ahmad, Syarwani. 2014. Komunikasi Antarpribadi: Perilaku Insani dalam Organisasi Pendidikan. Jakarta: PT. RajaGrafindoPersada. 
Irianto, Agus. 2015. Statistik: Konsep Dasar, Aplikasi dan Pengembangannya. Jakarta: Kencana.

Iskandar. 2011. Teknik Analisis Data Kuantitatif dan Kualitatif. Jakarta: GP Press.

KBBI. 2002. Jakarta: Balai Pustaka.

Knapp, Mark L. 1978. Nonverbal Communication in Human Interaction. Austin: Holt, Rinehart and Winston.

Morissan, M.A.,Teori Komunikasi Massa, PT Ghalia Indonesia, Bogor 2010.

Mulyana, Deddy. 2007. Ilmu Komunikasi: Suatu Pengantar. Bandung: PT. Remaja Rosdakarya.

Soekartawi. 2005. Prinsip Dasar Komunikasi Pertanian. Jakarta:Universitas Indonesia Press.

Sugiyono. 2012. Metode Penelitian Kuantitatif Kualitatif dan R\&D. Bandung: Alfabeta.

Syadzwina, A. Widya Warsa dan Akbar, Muhammad dan Bahfiarti, Tuti. 2014. Fenomenologi Perilaku Komunikasi Suporter Fanatik Sepakbola dalam Memberikan Dukungan pada PSM Makassar. Komunikasi KAREBA. 3(1).

\section{Website Source:}

Arum Puspita Dewi, Bahaya Kecanduan Gadget bagi Remaja, accessed on August 18, 2016 from https://teen.kapanlagi.com/girls/lifestyle/bahaya-kecanduan-gadget-bagi-remaja-005093.html

Irma Gustiana Andriani, M.Psi. ,Kenali Ciri Anak Kecanduan Gadget, accessed on November 29, 2016 from http://www.womanblitz.com/kenali-ciri-anak-kecanduan-gadget-276.html.

Mohamad Taufik, Asal-Usul Gadget, accessed on October 11, 2016 from http://www.merdeka.com/peristiwa/ asal-usul-gadget.htmlcg4.

Yoga Hastyadi Widiartanto, 2016, Pengguna Internet di Indonesia Capai 132 Juta, accessed on November 8, 2016 from http://tekno.kompas.com/read/2016/10/24/15064727/2016.pengguna.internet.di.indonesia.capa i.132.juta. 